\title{
Heavy metals residues of public health significance in some freshwater fish farmed in Kafr-El Sheikh and Menofia governorates
}

\author{
Nasser F. S. Ali, Hussein M. H. Mohamed and Fathi A. M. El-Nawawi* \\ Department of food Hygiene and Control, Faculty of Veterinary Medicine, \\ Cairo University
}

\begin{abstract}
The main objective of the current study was to estimate the levels of heavy metals residues in the flesh of farmed freshwater fish and fresh water samples collected from different localities. Fifty random fresh fish samples (20 cultured, Oreochromis niloticus, 20 cultured African catfish and 10 cultured Mugil cephalus) and 30 fresh water samples were collected from Kafr-El Sheikh governorate Moreover, forty fish samples (20, cultured Oreochromis niloticus and 20 cultured African catfish) and 20 water samples were collected from Menofia governorate. The fish samples were collected from the same sites and at the same times where water samples were collected throughout two successive years of (2013-2014). Collected cultured fresh fish and water samples were analyzed for heavy metal residues using Atomic Absorption Spectrophotometer (AAS). The results indicated that the concentration of Mercury, Lead, Cadmium and Arsenic residues in fresh water were higher than their levels in fish flesh samples under the study. Also the results indicated that the concentration of Mercury, Lead, Cadmium and Arsenic residues in both fresh water and fish flesh samples in Menofia were higher than their levels in Kafr- El Sheikh. The results revealed that the concentration of Mercury, Lead, Cadmuim and Arsenic residues in the flesh of cultred African catfish were higher than the permissible limits recommended by E.O.S.Q.C (2010) and FAO/WHO (1992) in both governorates under the study and the least concentration of such heavy metals residues was found to be in flesh of cultured Oreochromis niloticus followed by cultured Mugil cephalus.
\end{abstract}


Keywords: heavy metals, fresh water, atomic absorption, fresh fish.

\section{Introduction}

Fish and fish products are considered as a main source of animal proteins of high biological value, easily digestible and of high nutritional constituent due to its generous supply of minerals and vitamins. Consumption of fish provides a source of lean protein, highly enriched with omega-3 fatty acids and essential nutrients; however, it may be a main source of heavy metals which constitutes a risk for human if harvested from water contains high concentration of these metals (Petre et al., 2012).

The world aquaculture production showed that freshwater fishes are the dominant species of fish with a production of 28.8 million tons (54.7 percent) valued at US $\$ 40.5$ billion (41.2 percent) followed by mollusks (FAO, 2014). Fish can be considered as one of the main sources of the national income that Egypt depends on, stimulating local market economies, and important source of foreign exchange (Sadek, 2000).

In recent years, the unscrupulous industrial practices and environmental pollution can result in dissipation of heavy metals to water and concentration of these metals and other environmental agents that are related to environmental toxicity in farmed fish (Noveli et al., 1998). The pollution of aquatic environment with heavy metals constitutes a serious public health hazards for human being. Freshwater fish is more sensitive to heavy metals than marine species especially those of public health significance (Sorensen, 1991).

Heavy metals are persistent type of pollutants and cannot be broken down or destroyed over long time of heat treatment and become permanent additives to aquatic environment and their persistence enhances their potential to reach and affect human health (Levensen and Barnard, 1998). From public health point of view heavy metals including Mercury, Lead, Cadmium and Arsenic are of our primary concern because they are toxic for human being even if present in traces and they are always present in high concentration in wastes disposed in water of Nile 
river and Lakes. (Abd El-Kader, 1993). To the best of our knowledge, there is a limited data on the level of contamination of fresh water fish with heavy metals in Menofia and Kafr-El-sheikh governorates. Therefore, the main objective of the current study was to estimate the levels of Mercury, Lead, Cadmium and Arsenic in the flesh of cultured Oreochromis niloticus, African catfish and Mugil cephalus as well as in the fresh water collected from both governorates.

\section{Materials and Methods}

\section{Collection of samples}

Fifty fresh fish samples (20 cultured Oreochromis niloticus, 20 cultured African catfish and 10 cultred Mugil cephalus) and 30 water samples were collected from Kafr-El sheikh Moreover, forty fresh samples (20 cultured Oreochromis niloticus and 20 cultured African catfish) and 20 water samples were collected from Menofia. The body weight of cultured Oreochromis niloticus and African catfish specimens were ranged from 50 - $200 \mathrm{gm}$ and $100-400 \mathrm{gm}$ respectively. The water samples were collected according to the technique described by $\boldsymbol{A}$. P. H. A (1995).

\section{Preparation and analysis of water samples}

The water samples were preserved by addition of one $\mathrm{ml}$ of concentrated nitric acid until analysis. The analysis was conducted according to A.P.H.A. (1985) using UNICAM 696 AA spectrometer for measuring levels of lead, cadmium and arsenic and cold vapour technique for measuring mercury levels.

\section{Preparation and analysis of fish samples}

\section{Digestion and analysis}

Each fish sample was represented by one gram of flesh dissected from the axial muscles behind the head. The samples were prepared and digested according to the technique described by Shibamoto and Bjeldanes (1993). For detection of Cadmium and Lead, $1 \mathrm{gm}$ of each sample was digested by $10 \mathrm{ml}$ of digestion mixture in screw capped tube after maceration by sharp scalpel (Finerty et al., 
1990). In regard to mercury and arsenic, 0.5 gm of macerated sample was digested in $10 \mathrm{ml}$ concentrated H2SO4/HNO3 solution (1:1) as described by (Diaz et al., (1994). All tubes were tightly closed, shaked and allowed to stand overnight at room temperature, then heated for 4 hours in water bath at $70^{\circ} \mathrm{C}$ to ensure complete digestion followed by cooling at room temperature. The digest was filtered with whattman filter paper and the filtrate was collected in Pyrex glass test tubes capped with polyethylene film and kept at room temperature until analyzed for heavy metal contents using UNICAM969AA spectrophotometer). Estimation of heavy metals in each examined sample was expressed by $(\mathrm{mg} / \mathrm{kg})$ of wet weight samples.

\section{Quantitative determination of heavy metal residues}

Arsenic, Cadmium and Lead absorbency were recorded directly from the digital scale of AAS and their concentrations were calculated according to the following equation $\mathrm{C}=\mathrm{R}^{*}(\mathrm{D} / \mathrm{W})$

Where, $\quad \mathrm{C}=$ concentration of metal $(\mathrm{mg} / \mathrm{kg})$ wet weight

$\mathrm{R}=$ Reading of digital scale of AAS.

$\mathrm{D}=$ Dilution of prepared sample.

$\mathrm{W}=$ Weight of sample.

While, mercury concentration calculated according to the following equation $\mathrm{Cl}=$ $(\mathrm{A} 1 / \mathrm{A} 2) * \mathrm{C} *(\mathrm{D} / \mathrm{W})$.

Where, $\quad \mathrm{C} 1=$ concentration of mercury $(\mathrm{mg} / \mathrm{kg})$ wet weight.

$\mathrm{A} 1=$ Absorbency reading of the sample solution.

$\mathrm{A} 2=$ Absorbency reading of the standard solution .

\section{Statistical analysis:}

The data of heavy metal concentrations were statistically analyzed using Chi-square, ANOVA and t-test according to (SAS, 1987). After that the results presented in the form of figures according to Harvard graphics 4 computer programs. 


\section{Results and discussion}

Incidence of heavy metals residues in fresh water samples.

Table (1): Incidence of heavy metals residues in fresh water samples collected from Kafr- El sheikh and Menofia governorates.

\begin{tabular}{|c|c|c|c|c|}
\hline \multirow{2}{*}{ Metal } & \multicolumn{2}{|c|}{ Kafr- El sheikh $(n=30)$} & \multicolumn{2}{|c|}{ Menofia (n= 20) } \\
\hline & $\begin{array}{l}\text { No. of samples } \\
\text { exceeded the PL }\end{array}$ & $\%$ & $\begin{array}{l}\text { No. of samples } \\
\text { exceeded the PL }\end{array}$ & $\%$ \\
\hline $\mathrm{Hg}$ & 28 & 93.34 & 19 & 95 \\
\hline $\mathbf{P b}$ & 14 & 46.67 & 19 & 95 \\
\hline $\mathbf{C d}$ & 22 & 73.34 & 20 & 100 \\
\hline As & 23 & 76.67 & 20 & 100 \\
\hline
\end{tabular}

$\mathrm{Chi}^{2}=15.35^{\mathrm{B}} \quad \mathrm{B}=$ significant at $(\mathrm{P}<0.01)$

PL: permissible limit.

Table (2): Mean values of heavy metals in fresh water samples collected from Kafr- El sheikh and Menofia governorates

\begin{tabular}{|c|c|c|c|c|c|}
\hline \multirow{2}{*}{ Locality } & \multirow{2}{*}{$\begin{array}{c}\text { Safe } \\
\text { permissible } \\
\text { limits (PPM) } \\
\text { FAO/ WHO } \\
(1984)\end{array}$} & \multirow{2}{*}{$\begin{array}{c}\text { Kafr-El- sheikh } \\
\text { Mean } \pm \text { SE }\end{array}$} & \multirow{2}{*}{$\begin{array}{c}\text { Menofia } \\
\text { Mean } \pm \\
\text { SE }\end{array}$} & \multirow{2}{*}{$\begin{array}{c}\text { t- } \\
\text { value }\end{array}$} & \multirow{2}{*}{$\begin{array}{c}\begin{array}{c}\text { Overall } \\
\text { mean }\end{array} \\
\text { Mean } \pm \mathrm{SE}\end{array}$} \\
\hline & & & & & \\
\hline $\mathrm{Hg}$ & 0.001 & $0.25 \pm 0.06^{\mathrm{a}}$ & $\begin{array}{c}0.19 \pm \\
0.04^{\mathrm{b}}\end{array}$ & $1.72^{\mathrm{A}}$ & $0.22 \pm 0.04$ \\
\hline $\mathbf{P b}$ & 0.05 & $0.29 \pm 0.07^{\mathrm{a}}$ & $\begin{array}{c}0.43 \pm \\
0.10^{\mathrm{b}}\end{array}$ & $2.17^{\mathrm{A}}$ & $0.35 \pm 0.06$ \\
\hline Cd & 0.005 & $0.24 \pm 0.07^{\mathrm{a}}$ & $\begin{array}{c}0.68 \pm \\
0.17^{\mathrm{b}}\end{array}$ & $2.41^{\mathrm{B}}$ & $0.42 \pm 0.09$ \\
\hline As & 0.01 & $0.43 \pm 0.15^{\mathrm{a}}$ & $\begin{array}{l}4.11 \pm \\
0.57^{\mathfrak{b}}\end{array}$ & $7.27^{\mathrm{B}}$ & $1.95 \pm 0.35$ \\
\hline
\end{tabular}

Means within the same row of different litters are significantly different $A=$ significant at $(P<0.05)$

$B=$ significant at $(P<0.01)$

$\mathrm{C}=$ significant at $(\mathrm{P}<0.001)$

The results recorded in Table (1) revealed that the percentage of sample exceeded the permissible limits recommended by $\boldsymbol{F A O / W H O}$ (1984) for $\mathrm{Hg}, \mathrm{Pb}$, $\mathrm{Cd}$ and As in water samples collected from Kafr-Elsheikh were 93.34\%, 46.67\%, $73.34 \%$ and $76.67 \%$, respectively. However, the percentage of samples exceeded the permissible limits for these heavy metals in Menofia were 95\%, 95\%, 100\% and $100 \%$, respectively. Moreover, the result in Table (2) revealed that the mean 
values of concentration of $\mathrm{Hg}$ in water samples collected from Menofia were significantly $(\mathrm{P}<0.05)$ lower than the concentration of this heavy metal in samples collected from Kafr- El sheikh, however, the concentrations of $\mathrm{Pb}, \mathrm{Cd}$ and As in samples collected from Menoifa were significantly $(\mathrm{P}<0.05)$ higher than the concentration of these heavy metals in samples collected from Kafr- El sheikh.

Table (3): Incidence of heavy metals residues in cultured Oreochromis niloticus samples harvested from Kafr- El sheikh and Menofia governorates.

\begin{tabular}{|c|c|c|c|c|}
\hline \multirow{2}{*}{\begin{tabular}{c} 
Mocality \\
\cline { 2 - 5 }
\end{tabular}} & $\begin{array}{c}\text { Kafr- El sheikh }(\mathbf{n}=\mathbf{3 0}) \\
\begin{array}{c}\text { No. of samples } \\
\text { exceeded the PL }\end{array}\end{array}$ & $\%$ & $\begin{array}{c}\text { Mo. of samples } \\
\text { exceeded the PL }\end{array}$ & $\%$ \\
\hline \hline $\mathbf{H g}$ & 2 & 10 & 1 & 5 \\
\hline $\mathbf{P b}$ & 2 & 10 & 10 & 50 \\
\hline $\mathbf{C d}$ & 5 & 25 & 12 & 60 \\
\hline $\mathbf{A s}$ & 4 & 20 & 20 & 100 \\
\hline
\end{tabular}

$\mathrm{Chi}^{2}=11.25^{\mathrm{B}} \quad \mathrm{B}=$ significant at $(\mathrm{P}<0.01)$

PL: permissible limit.

Table (4): Mean values of heavy metal residues in cultured Oreochromis niloticus samples harvested from Kafr- El sheikh and Menofia governorates (ppm, wet weight) $(n=40)$.

\begin{tabular}{|c|c|c|c|c|c|}
\hline & & Kafr-El- sheikh & Menofia & & Overall mean \\
\hline Metals & $\begin{array}{c}\text { permissible } \\
\text { limits (PPM) } \\
\text { (E. O.S Q. C } \\
(2010) ; \\
\text { FAO/WHO } \\
(1992)\end{array}$ & Mean \pm SE & Mean \pm SE & t-value & Mean \pm SE \\
\hline$* \mathbf{H g}$ & $\overline{\overline{0.5}}$ & $0.08 \pm 0.04^{\mathrm{b}}$ & $0.16 \pm 0.02^{\mathrm{a}}$ & $1.84^{\mathrm{A}}$ & $\overline{0.12 \pm 0.02}$ \\
\hline$* \mathbf{P b}$ & 0.3 & $0.08 \pm 0.03^{b}$ & $0.40 \pm 0.05^{\mathrm{a}}$ & $3.33^{B}$ & $0.24 \pm 0.05$ \\
\hline * Cd & 0.1 & $0.08 \pm 0.02^{b}$ & $0.60 \pm 0.11^{\mathrm{a}}$ & $3.42^{\mathrm{B}}$ & $0.34 \pm 0.09$ \\
\hline$* * \mathbf{A s}$ & 0.03 & $0.33 \pm 0.22^{b}$ & $3.11 \pm 0.5^{\mathrm{a}}$ & $6.13^{\mathrm{C}}$ & $1.72 \pm 0.40$ \\
\hline
\end{tabular}

$*=$ (E. O.S Q. C (2010)

$* *=(\mathrm{FAO} / \mathrm{WHO}(1992)$

Means within the same row of different litters are significantly different.

$A=$ significant at $(P<0.05)$

$B=$ significant at $(P<0.01)$

$\mathrm{C}=$ significant at $(\mathrm{P}<0.001)$ 
The results recorded in Table (3) revealed that the percentage of samples exceeded the permissible limits recommended by $E$. O. S.Q. C (2010) and (FAO/ WHO 1992) for $\mathrm{Hg}, \mathrm{Pb}, \mathrm{Cd}$ and $\mathrm{As}$ in Kafr- El sheikh were 10\%, 10\%, $25 \%$ and $20 \%$, respectively. However, the percentage of samples exceeded the permissible limits for these heavy metals in Menofia were 5\%, 50\%, 60\% and $100 \%$, respectively. While, the results in Table (4) revealed that the mean values of concentration of $\mathrm{Hg}, \mathrm{Pb}, \mathrm{Cd}$ and $\mathrm{As}$ in samples collected from Menofia were significantly $(\mathrm{P}<0.05)$ higher than the concentration of these heavy metals in samples collected from Kafr- El sheikh.

Table (5): Incidence of heavy metals residues in cultured African catfish samples harvested from Kafr- El sheikh and Menofia governorates.

\begin{tabular}{|c|c|c|c|c|}
\hline \multirow[b]{2}{*}{ Metal } & \multicolumn{2}{|c|}{ Kafr- El sheikh $(n=20)$} & \multicolumn{2}{|c|}{ Menofia $(n=20)$} \\
\hline & $\begin{array}{l}\text { No. of samples } \\
\text { exceeded the PL }\end{array}$ & $\%$ & $\begin{array}{l}\text { No. of samples } \\
\text { exceeded the PL }\end{array}$ & $\%$ \\
\hline $\mathbf{H g}$ & $\overline{5}$ & 25 & 2 & 10 \\
\hline $\mathbf{P b}$ & 3 & 15 & 11 & 55 \\
\hline $\mathbf{C d}$ & 7 & 35 & 16 & 80 \\
\hline As & 4 & 20 & 20 & 100 \\
\hline
\end{tabular}

$\mathrm{Chi}^{2}=10.44^{\mathrm{B}}$

$B=$ significant at $(P<0.01)$

PL: permissible limit.

Table (6): Mean values of heavy metal residues in cultured African catfish samples harvested from Kafr- El sheikh and Menofia governorates (ppm, wet weight $)(n=40)$.

\begin{tabular}{|c|c|c|c|c|c|}
\hline \multirow{2}{*}{ Mecality } & \multirow{2}{*}{$\begin{array}{c}\text { Safe permissible } \\
\text { limits (PPM) } \\
\text { (E. O.S Q. C } \\
(2010) ; \\
\text { FAO/ WHO } \\
(1992)\end{array}$} & $\begin{array}{l}\text { Kafr-El- } \\
\text { sheikh }\end{array}$ & Menofia & \multirow{2}{*}{$\begin{array}{c}\text { t- } \\
\text { value }\end{array}$} & Overall mean \\
\hline & & Mean $\pm S E$ & Mean \pm SE & & Mean \pm SE \\
\hline * Hg & 0.5 & $0.14 \pm 0.06^{b}$ & $0.22 \pm 0.04^{\mathrm{a}}$ & $2.22^{\mathrm{A}}$ & $0.18 \pm 0.03$ \\
\hline$* \mathbf{P b}$ & 0.3 & $0.10 \pm 0.04^{b}$ & $0.43 \pm 0.06^{\mathrm{a}}$ & $4.23^{\mathrm{B}}$ & $0.27 \pm 0.05$ \\
\hline$* \mathbf{C d}$ & 0.1 & $0.15 \pm 0.04^{\mathrm{b}}$ & $0.64 \pm 0.12^{a}$ & $3.77^{\mathrm{B}}$ & $0.40 \pm 0.07$ \\
\hline$* * \mathbf{A s}$ & 0.03 & $0.03 \pm 0.00^{\mathrm{b}}$ & $4.36 \pm 0.54^{\mathrm{a}}$ & $7.78^{C}$ & $2.25 \pm 0.44$ \\
\hline
\end{tabular}

$*=$ (E. O.S.Q. C (2010)

$* *=(\mathrm{FAO} / \mathrm{WHO}(1992)$

Means within the same row of different litters are significantly different.

$A=$ significant at $(P<0.05)$

$B=$ significant at $(P<0.01)$

$\mathrm{C}=$ significant at $(\mathrm{P}<0.001)$ 
The results recorded in Table (5) revealed that the percentage of sample exceeded the permissible limits recommended by $E$. O. SQ. $C$ (2010) and FAO/WHO 1992) for $\mathrm{Hg}, \mathrm{Pb}, \mathrm{Cd}$ and $\mathrm{As}$ in African catfish in Kafr- El sheikh were $25 \%, 15 \%, 35 \%$ and $20 \%$, respectively. However, the percentage of sample exceeded the permissible limits for these heavy metals in Menofia were $10 \%$, $55 \%, 80 \%$ and $100 \%$, respectively. While, the results in Table(6) revealed that the mean values of concentrations of $\mathrm{Hg}, \mathrm{Pb}, \mathrm{Cd}$ and $\mathrm{As}$ in samples collected from Menofia were significantly $(\mathrm{P}<0.05)$ higher than the concentration of these heavy metals in samples collected from Kafr- El sheikh.

Table (7): Incidence of heavy metals residues in cultured Mugil cephalus samples harvested from Kafr- El sheikh governorate.

\begin{tabular}{|c|c|c|}
\hline \multirow{2}{*}{$\begin{array}{c}\text { Locality } \\
\text { Metal }\end{array}$} & $\begin{array}{c}\text { Kafr- El sheikh }(\mathrm{n}=\mathbf{1 0}) \\
\text { No. of samples exceeded } \\
\text { the PL }\end{array}$ & $\%$ \\
\hline $\mathbf{H g}$ & 1 & 10 \\
\hline $\mathbf{P b}$ & 3 & 30 \\
\hline $\mathbf{C d}$ & 4 & 40 \\
\hline $\mathbf{A s}$ & 6 & 60 \\
\hline $\mathbf{C h i}^{\mathbf{2}} \mathbf{\mathbf { 5 . 4 4 }}$ & \multicolumn{2}{|c|}{$\mathbf{B}=$ significant at $(\mathbf{P}<\mathbf{0 . 0 1})$}
\end{tabular}

PL: permissible limit.

Table (8): Mean values of heavy metals residues in cultured Mugil cephalus samples harvested from Kafr- El sheikh governorate (ppm, wet weight) (n $=10$ ).

\begin{tabular}{|c|c|c|}
\hline $\begin{array}{c}\text { Locality } \\
\text { Metal }\end{array}$ & $\begin{array}{c}\text { Safe permissible limits } \\
\text { (PPM) } \\
\text { (E. O.S Q. C (2010); } \\
\text { FAO/ WHO (1992) }\end{array}$ & Kafr- El sheikh \\
\cline { 2 - 3 }$*$ Hg & 0.5 & $0.13 \pm 0.01$ \\
\hline$*$ Pb & 0.3 & $0.09 \pm 0.001$ \\
\hline$*$ Cd & 0.1 & $0.14 \pm 0.01$ \\
\hline$* * A s$ & 0.03 & $0.02 \pm 0.001$ \\
\hline$*$ (E.O.S. Q. C 2010).
\end{tabular}

The results recorded in Tables (7) and (8) revealed that the \% of samples exceeded the permissible limits recommended by (E. O. S Q. C 2010) and (FAO/ WHO 1992) for $\mathrm{Hg}, \mathrm{Pb}, \mathrm{Cd}$ and $\mathrm{As}$ in cultured Mugil cephalus samples 
$10 \%, 30 \%, 40 \%$ and $60 \%$ respectively. Also the mean concentration values of $\mathrm{Hg}, \mathrm{Pb}, \mathrm{Cd}$ and As samples in Kafr- Elsheikh were 0.13, 0.09, 0.14 and 0.02 respectively.

The observed results were in agreement with previous researchers who reported that the incidence of heavy metals residues contamination of fresh water and fish differ from locality to another according to the source and degree of pollution of water (Hem,1972) (Horvarth and Mattraw, 1972) El-Nabawi et al., 1987).

These higher concentrations of heavy metals in Menofia may be attributed to the contamination of water in this governorate with the drainage of factories in the Quesna industrial region. The higher concentrations of Cadmium and Arsenic than those of Mercury and lead may be explained by higher concentration of these metals in the drainage of these factories. This explanation is in agreement with (Davis (1984) who reported that the elevation of Cadmium and Arsenic levels in water and fish muscle samples may be attributed to collection of the examined samples from contaminated aquaculture exposed to, combustion of gasoline and drainage of industrial factories.

The results recorded in Tables 2, 4, 6 and 8 indicated that the concentrations of heavy metals residues in fresh water were higher than their levels in fish flesh samples under the study. These results were in agreement with those of (Puel et al., (1987), (abdo Lahpur monikh et al., (2013) who reported that the concentrations of heavy metals in water was higher than their concentrations in the fish flesh. However, these results were in disagreement with those of (Storelli et al., (2002) who reported that the concentration of $(\mathrm{Pb})$ and $(\mathrm{Cd})$; in fish samples were several times higher than their concentration in water. The concentration of heavy metals residues in flesh of African catfish was higher than that of Oreochromis niloticus in different localities under the study. The results were in agreement with the results of (Dsikowitzky et al., (2013) who reported that African catfish commonly exposed to the heavy metals contamination more than other types of fish as Mugil cephalus and Oreochromis 
niloticus. Moreover, the results were also in agreement with the results of (Elsadaawy et al., (2013) who reported that by increasing the size and body length of the fish there is increasing in the surface area of fish and consequently increasing of heavy metals bioaccumulations in fish. In general, the bioaccumulation of heavy metal residues' in fresh, fish flesh may be attributed to different factors such as fish species, age of fish, lipid content of fish, mode of feeding and the level of water column in 'which fish living either pelagic or benthic fish.

\section{Conclusion}

It can be concluded from this study that the incidence of heavy metals contamination of fresh water and fish differ from locality to another according to the source and degree of water pollution. Fresh water and fish species contamination with heavy metals residues in Menofia is higher than that of KafrElsheikh. Consumption of Oreochromis niloticus followed by Mugil cephalus is safe on human health than other types of fish species under the study due to its low content of heavy metals residues in its flesh.

\section{References}

Abd El- Kader, M. A. (1993): "Metal Poisoning in fish". Oxford chapter 1, P. 111; chapter 8, P. 290 and I.B.H. Publishing Co. Bombay.

Abdolahpur Monikh F, Safahieh A, Savari A, Ronagh MT, Doraghi A. (2013): The Relationship between Heavy metals ( $\mathrm{Cd}, \mathrm{Co}, \mathrm{Cu}, \mathrm{Ni}$ and $\mathrm{Pb}$ ) levels and the Size of Benthic, Benthopelagic and Pelagic Fish Species, Persian Gulf. Bull Environ. Contam. Toxicol. 2013 Mar 27. [Epubahead of Print].

A.P.H.A. "American Public Health Association" (1985): Standard Methods for the Examination of Water and Wastewater. 16 ${ }^{\text {th }}$ Washington D. C. 2005.

A.P.H.A "American Public Health Association" (1995): Standard Methods for the Examination of Water and Wastewater. 19 ${ }^{\text {th }}$ Washington D. C. 2005.

Davis, R. D. (1984): "Cadmuim; a Complex Environmental Problem. "Expermentia, 40: 117-126. 
Diaz, C.; Gonzalez- Pardon, A.; Frias, I. ; Hardisson, A. and Lozano, G. (1994): "Concentration of Mercury in Fresh and Salted Marine Fish from the Cannery Islands." J. Food Protec., 57, 3, 246- 248.

Diskowitzky L, Mengesha M, Dadebo E, de Carvalho CE, Sindern S. (2013): Assesment of Heavy Male in Water Samples and Tissues of Edible Fish Species from Awassa and Koka Rift Valley Lakes, Ethiopia Environ. Monit. Assess. 2013 Apr; 185 (4): 117-31. Doi:10.1007s10661-012-27778.Epub2012Jul22.

E.O.S.Q.C "Egyptian Organization for Standardization and Quality Control"'(2760/2010): Physical and Chemical Methods for Testing Fish and Fish and Fisher Products". Part 5: Crustacea and Mollusca, Egyptian Organization for Standardization and Quality Control. U.D.C: 637/6642010 Arab Republic.

El-Nabawi, A.; Heinzow, B. and Kruse, H. (1987): " $\mathrm{As}, \mathrm{Cd}, \mathrm{Pb}, \mathrm{Hg}$ and $\mathrm{Zn}$ in Fish from the Alexandria Region Egypt", Bull. Environ. Contam. Toxicol., 39, 889- 897.

El- Sadaawy, M. M., El- Said, G.F., Sallam N. A. (2013): Bio Availability of Heavy Metals in Fresh Water Oreochromis Niloticus Linnaeus, 1758): Potential Risk to Fisher Men and Consumers. J Environ. Sci Health B. 2013; 48 (5): 402- 9. Doi: 10.1080/03601234.2013.742719.

FAO/ WHO, (1984): List of Maximum Levels Recommended for Contaminants by the Joint FAO. WHO Codex Alimentarius Commission. Second Series. CAC/ FAL 3:1-8.

FAO/ WHO, (1992): "Codex Alimentarius Commission Standard Programme Codex Committee on Food Additives and Contaminants." $24^{\text {th }}$ Session, Hague, 23-28 March, 1992.

FAO, "Food and Agriculture Organization". (2014): Overview of Fish Production, Utilization, Consumption and Trade FAO, Rome, Italy.

Finerty, M. W.; Madden, J.D.; Feagly, S.E; Grodner, R. M. (1990): "Effect of Environment and Seasonality on Metal Residues in Tissues of Wild and Pond Raised Crayfish in Southern Loisiana" Arch. Environ. Contam. Toxicol. 19, 94- 100.

Hem, J. D. (1972): Water Resources Res. 8: 61. (Cited After Faust and Aly, 1981).

Horvarth, G. R. H and Mattraw, H. C. (1972): Land Development and Trace Metal Distribution in the Florida Everglades. Mar. Pollution Bull. 3: 182- 83.

Levensen, H. and Barnard, W.D. (1988): "Wastes in Marine Environments". Hemisphere Publishing Corporation Cambridge. New York, London. Chap. 6, PP. 123- 126.

Novelli, E. L.; Vierira, E. P. ; Rodrigues, N. L. and Ribas, B. O. (1998): Risks Assessment of Cadmium Toxicity on Hepatic and Renal Tissues of Rates. Environ. Pres. 79 (2): 102- 105. 
Petre S. J., Sackett D. K. Aday D. D. (2012): Do National Advisories Serve Local Consumers: An Assessment of Mercury in Economically Important North Carolina Fish. J Environ Monit. 2012 May; 14 (5): 1410-6. doi: 10.1039/c2em30024a.Epub2012Mar28.

Puel, D.; Zsuerger, N. and Breittmayer J. P. (1987): statistical assessment of a sampling pattern for evaluation of changes in $\mathrm{Hg}$ and $\mathrm{Zn}$ concentration in patella coerulea Bull-Enviorn. Contam. Toxicol., (38): 700-706.

Sadek, S. (2000): Seabream Culture in Egypt; Status, Constraints and Potential. Fish Physiol. Bioch., (22): 171- 178.

SAS (1987): "Statistical Analysis System". User’s Guide Statistics. SAS Institute Cary, North Carolina.

Shibamotio, T. and Bjeldanes, L. F. (1993): Introduction to Food Toxicology. San Diego, California, Food Science and Technology Journal, Academic Press- XIII, 2135.ISBNO-12-640025-3.

Sorensen, E. M. B. (1991): "Metal Poisoning in Fish". Oxford Chapter 1, P. 111; Chapter 8, P. 290 and I.B.H. Publishing Co. Bombay.

Storelli, M.; Giacominelli- Stuffer, $R$ and Marcon Trigiano, G. (2002): Mercury Accumulation and Speciation in Muscle Tissue of Different Species of Sharks from Mediterranean Sea. Italy. Bull. Environ. Contam. Toxicol. (68): 201- 210. 